"This article has been accepted for publication in AFRICAN JOURNAL OF AQUATIC SCIENCE, published by NISC (Pty) Ltd."

"This is an original manuscript of an article published by NISC (Pty) Ltd in

AFRICAN JOURNAL OF AQUATIC SCIENCE on 12 March 2021, available online:

https://doi.org/10.2989/16085914.2021.1887804

\title{
A review on the population of tilapiine species in Lakes Victoria and Naivasha, East Africa
}

\author{
${ }^{1}$ Edwine Yongo, ${ }^{2}$ Laurent Cishahayo \& ${ }^{3}$ Eunice Mutethya \\ ${ }^{1}$ Faculty of Life and Pharmaceutical Sciences, Hainan University, China. \\ ${ }^{2}$ Faculty of agricultural and forestry economic management, Hainan University, China. \\ ${ }^{3}$ Department of Fisheries \& Aquatic Sciences, University of Eldoret, Kenya.
}

\begin{abstract}
This paper discusses the status of tilapiine species both native and those introduced into Lakes Victoria and Naivasha. In Lake Victoria, Oreochromis niloticus, O. leucosticus, Coptodon zillii and Coptodon rendalii were introduced. Establishment of non-native species was associated with declines in the populations of the native O. esculentus and $O$. variabilis. Oreochromis niloticus dominates the commercial fishery, but populations of the other introduced species persist. Predation by Nile perch (Lates niloticus), overfishing, lake pollution and eutrophication have impacted negatively on the fish stocks. In Lake Naivasha, O. niloticus, C. zillii and O. esculentus were introduced. These species have also declined in catches due to the deteriorating lake conditions and effects of overfishing. Oreochromis leucostictus and O. niloticus dominate fishery catches, whereas $C$. zillii is rarely caught. The biological and population parameters of the tilapiines have shown great variations over time. $O$. niloticus and $O$. leucosticus attain early maturation. These changes are discussed as adaptive characteristics in response to intense fishing and changing ecological conditions. This therefore, calls for a need to improve on the management measures applicable in the two lake ecosystems, such as fishing effort control, pollution control and protecting the surrounding wetland from degradation.
\end{abstract}

Keywords: tilapiines catch trends, population biology 


\section{Introduction}

Tilapia is a common name for cichlid fishes comprising three genera; Oreochromis, Sarotherodon, Coptodon, Heterotilapia and Pelmatolapia (Dunz and Schliewen, 2013). Tilapias are freshwater fishes native to African continent (Philippart and Ruwet 1982). Nile tilapia, Oreochromis niloticus is one of the commercially most important tilapiine that has been introduced to various countries, primarily for purposes of aquaculture and stock enhancement. Nile tilapia is a favoured species for aquaculture expansion in Africa due to its growth performance, suitability for aquaculture, marketability and stable market prices (Shechonge et al. 2019). It has been introduced to lakes Naivasha and Victoria to provide exploitable fisheries. Nile tilapia is highly invasive and has established in Lake Victoria (Njiru et al. 2006). The bluespotted tilapia, O. leucostictus is native to Lakes Edward, George and Albert (Trewavas 1983). The red-belly tilapia, $C$. zillii is also native to Lakes Turkana, Albert and parts of the Nile. Tilapias adapt well to fast flowing rivers and in lakes where they occupy the shallow inshore waters purposely as feeding and reproductive grounds. They are known to tolerate harsh environmental conditions including high salinity, high water temperature, low dissolved oxygen and high ammonia concentrations (Philippart and Ruwet 1982). In habitats where they have been introduced, tilapias out-compete native species for food, habitat and spawning sites (Gu et al. 2018). This is due to their adaptive characteristics such as tolerance to varying environmental conditions, prolific breeding, short generation time, extended breeding season, territoriality, mouthbrooding behavior and the ability to feed at a range of trophic levels (Russell et al. 2012). They also have diversified feeding pattern, thus are able to colonize various aquatic environments. Their feeding behavior ranges from generalist omnivores to opportunistic herbivores with diversified diets (Njiru et al. 2004). They are structurally adapted to their feeding mode by possessing long and coiled intestines that is almost fourteen times their body length, thus increasing surface area for digestion; presence of sharp pharyngeal teeth, bicuspid and tricuspid teeth of the jaws used for grinding/shredding food items (Trewavas 1983).

This paper discusses the status of tilapiine species both native and those introduced into Lakes Victoria and Naivasha. The focus on these two lakes was informed by the availability of adequate data from the previous studies. Some of the aspects reviewed were the introduction of tilapiines in the two lakes; changes in their catch, biological and population parameters in light of 
the fishing effects and the varying ecological conditions of the lakes. The findings from this review are useful to inform sustainable management of the fisheries. The review also provides an update on the tilapia fisheries in the two lakes.

\section{Lake Victoria Fishery}

\section{Fish introductions}

Lake Victoria is the second largest freshwater lake in the world and the largest in Africa. The lake is shared by Kenya (6\%), Tanzania (51\%), and Uganda (43\%) according to Johnson et al. (2000). The local communities in the catchment have relied on Lake Victoria for their livelihood for centuries. Before the introduction of exotic species, Lake Victoria had a multispecies fishery that comprised of over 500 endemic fish species, dominated primarily by the tilapiines $O$. esculentus and $O$. variabilis and, haplochromine cichlids (Ogutu-Ohwayo 1990). Other important species included Rastrineobola argentea, Protopterus aethiopicus, Bagrus docmak, Clarias gariepinus, Schilbe intermedius, Synodontis species, various Barbus species, and mormyrid species. Many of these native species have presently declined due to predation by Nile perch, hybridization and competition by Nile tilapia, and fishing pressure (Witte et al.1999). $O$. variabilis is recorded on the IUCN Red List as Critically Endangered. It is now almost entirely extirpated from its native range in the Lake Victoria catchment following introductions of Nile perch, Lates niloticus, O. niloticus and O. leucostictus from the 1950s onwards (Shechonge et al. 2019). Lates niloticus was introduced from Lake Albert into the Ugandan and Kenyan parts of Lake Victoria between 1954 and 1963, with the aims of creating a recreational fishery and converting the large biomass of the indigenous small bony haplochromine cichlids into a lessproductive, but more valuable commodity (Pringle 2005; Yongo et al. 2017a). The earliest introductions of $O$. niloticus into Lake Victoria took place during the 1950s (Goudswaard et al. 2002) and were sourced from elsewhere in Nile catchment, potentially Lake Edward (Mwanja et al. 2008). The blue-spotted tilapia (O. leucostictus) is naturally distributed in southerly reaches of the Nile system, including Lakes Edward, Albert and George. It was probably introduced to Lake Victoria alongside O. niloticus, Coptodon zillii and C. rendalii during the 1950s (Goudswaard et al. 2002). 


\section{Dominance of Nile tilapia}

The introduced tilapiine species quickly established themselves in the lake, particularly $O$. niloticus began to appear in commercial catches from 1960s onwards (Njiru et al. 2000). By 1970s, the catches of $O$. niloticus in Lake Victoria began to increase progressively until 1981, whereas catches of the native species $O$. esculentus continued to decline drastically (Figure 1). The increased dominance and establishment of $O$. niloticus over other tilapiines in Lake Victoria has been attributed to several factors. Nile tilapia and Nile perch are both native to Lake Albert, therefore it is possible that Nile tilapia has evolved behaviour patterns that allow it to minimize predation by Nile perch (Yongo et al. 2018). It is also hypothesized that $O$. niloticus could have co-existed with the Nile perch predation because of its faster growth rate traits unlike other tilapiines (Njiru et al. 2006). This could be evidenced in the Nile perch diet studies in which $O$. niloticus constituted least proportion as shown in figure 2 (Njiru et al. 2005; Outa et al. 2017; Agembe et al. 2018).

The diversified feeding mode of $O$. niloticus probably gave the species higher survival rate in the changing Lake Victoria ecosystem. It is an opportunistic omnivore with very diverse diet that includes insects, algae, fish, molluscs and detritus (Njiru et al. 2004). This feeding mode thus gave it a better competitive advantage against the other tilapiine species. The endemic $O$. esculentus feeds almost entirely on diatoms (Welcomme 1967); O. variabilis feeds mainly phytoplankton, whereas C. zillii feeds mostly macrophytes (Trewavas 1983). The interactions between native and exotic tilapias in Lake Victoria have become much more complex than expected (Welcomme 1967). Overlap has been observed between the diet of adult O. leucostictus and $O$. variabilis. The overlap also existed between the diets of juvenile $O$. esculentus and the three exotic tilapiines (Loiselle 1997). There was also overlap in habitat and preference for nursery area between $O$. variabilis and $O$. leucostictus, C. rendalii and C. zillii (Ogutu-Ohwayo 1990). A competitive interaction between introduced tilapiines and native species appeared to be the most plausible explanation for the decline of the latter species (Welcomme 1967). The introductions resulted in hybridization between $O$. variabilis and $O$. niloticus that caused decline in O. variabilis in some parts of the lake (Welcomme 1966, 1967).

The $O$. niloticus in Lake Victoria is more fecund, which has probably contributed to its success in the lake. Lowe-McConnell (1955) reports that $O$. variabilis produces 324-1627, $O$. 
leucostictus, 99-950, O. niloticus 340-3706 and C. zillii 1000-7061 eggs in Lake Victoria. The previous studies showed that the fecundity of $O$. niloticus has increased to $905-7619$ eggs for fish of 28-51 cm TL (Njiru et al. 2006). Water hyacinth (Eichornia crassipes) infestation in Lake Victoria provided feeding and breeding grounds for O. niloticus (Balirwa 1998; Njiru et al. 2004). Infestation of the lake by the water hyacinth also led to a drastic reduction in beach seining, a common fishing method in shallow waters, allowing the fish time to reproduce and grow (Njiru et al. 2005). This was shown by the increased catches of $O$. niloticus observed during the periods when water hyacinth infested Lake Victoria (Figure 3).

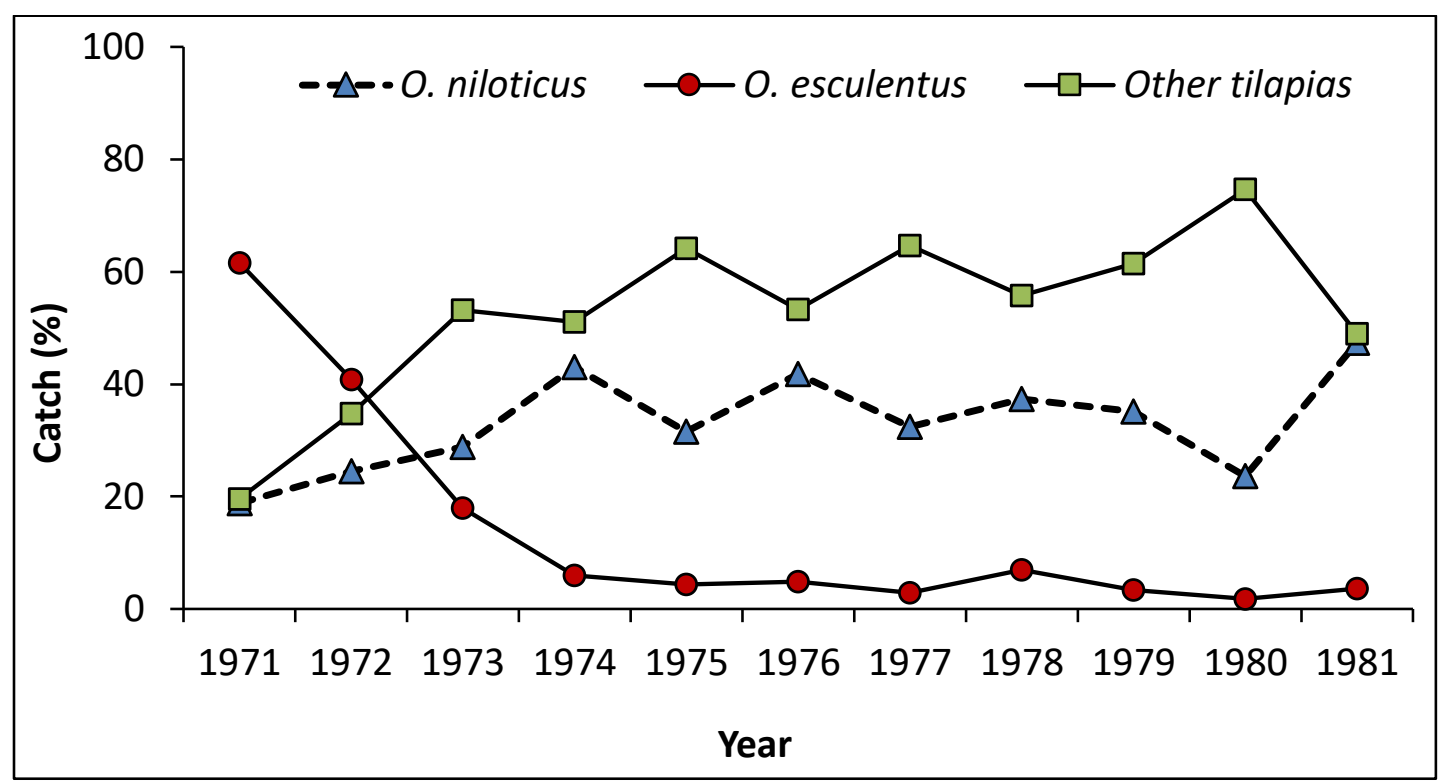

Figure 1: Trends in catches of the Tilapiine species in Lake Victoria 1971 to 1981 (data adapted from Wasonga et al. 2017).
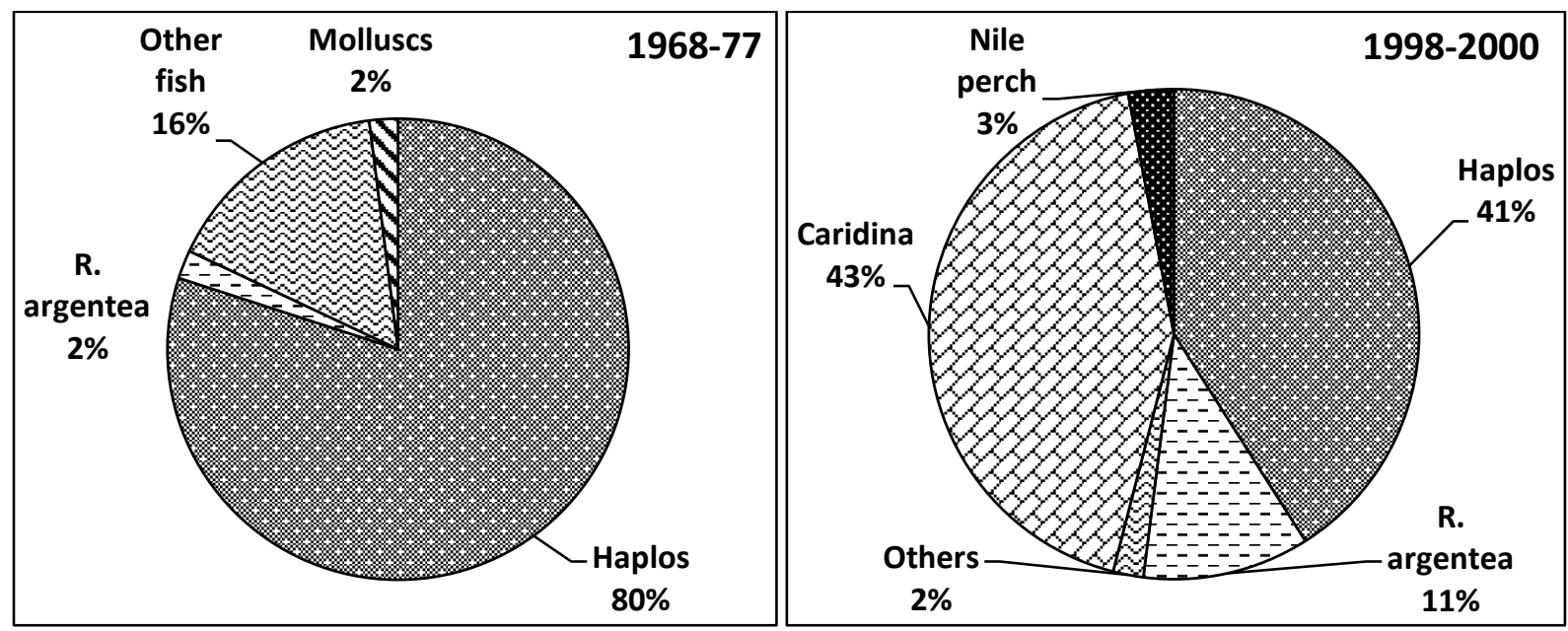


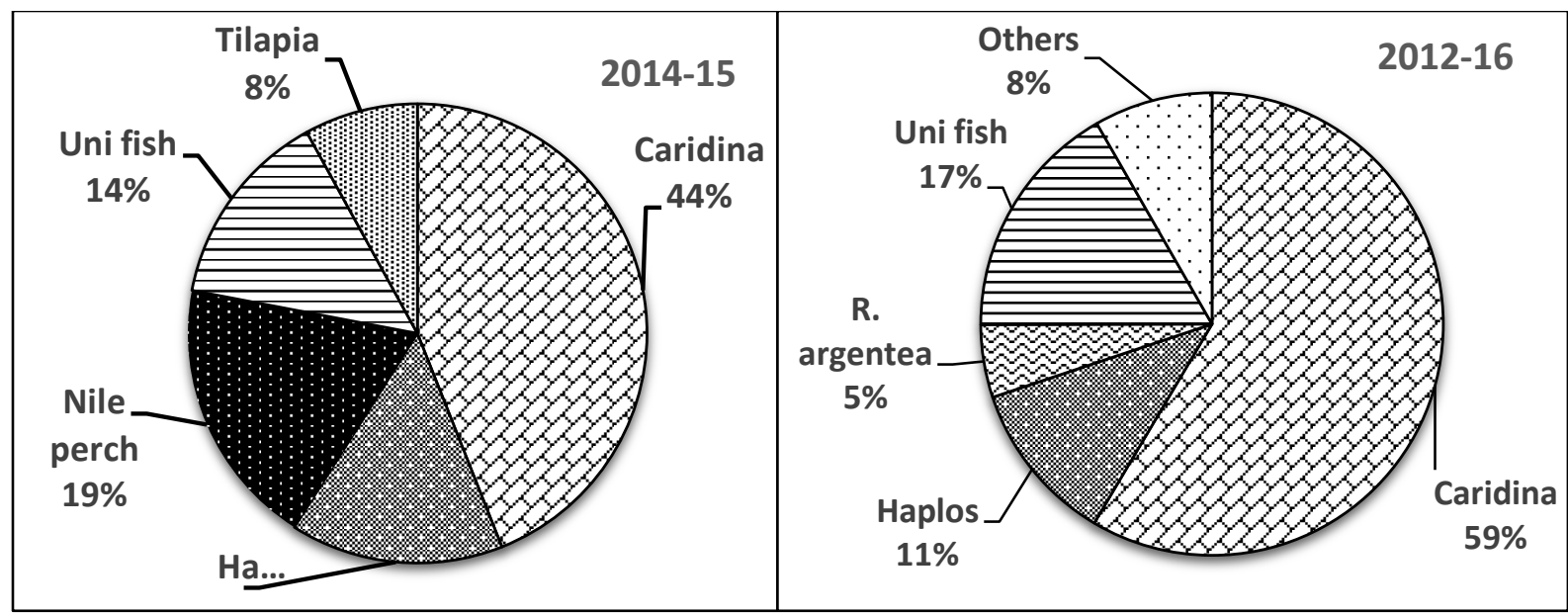

Figure 2: Diet of L. niloticus in Lake Victoria showing O. niloticus not contributing main diet. (data adapted from Njiru et al. 2005; Outa et al. 2017; Agembe et al. 2018).

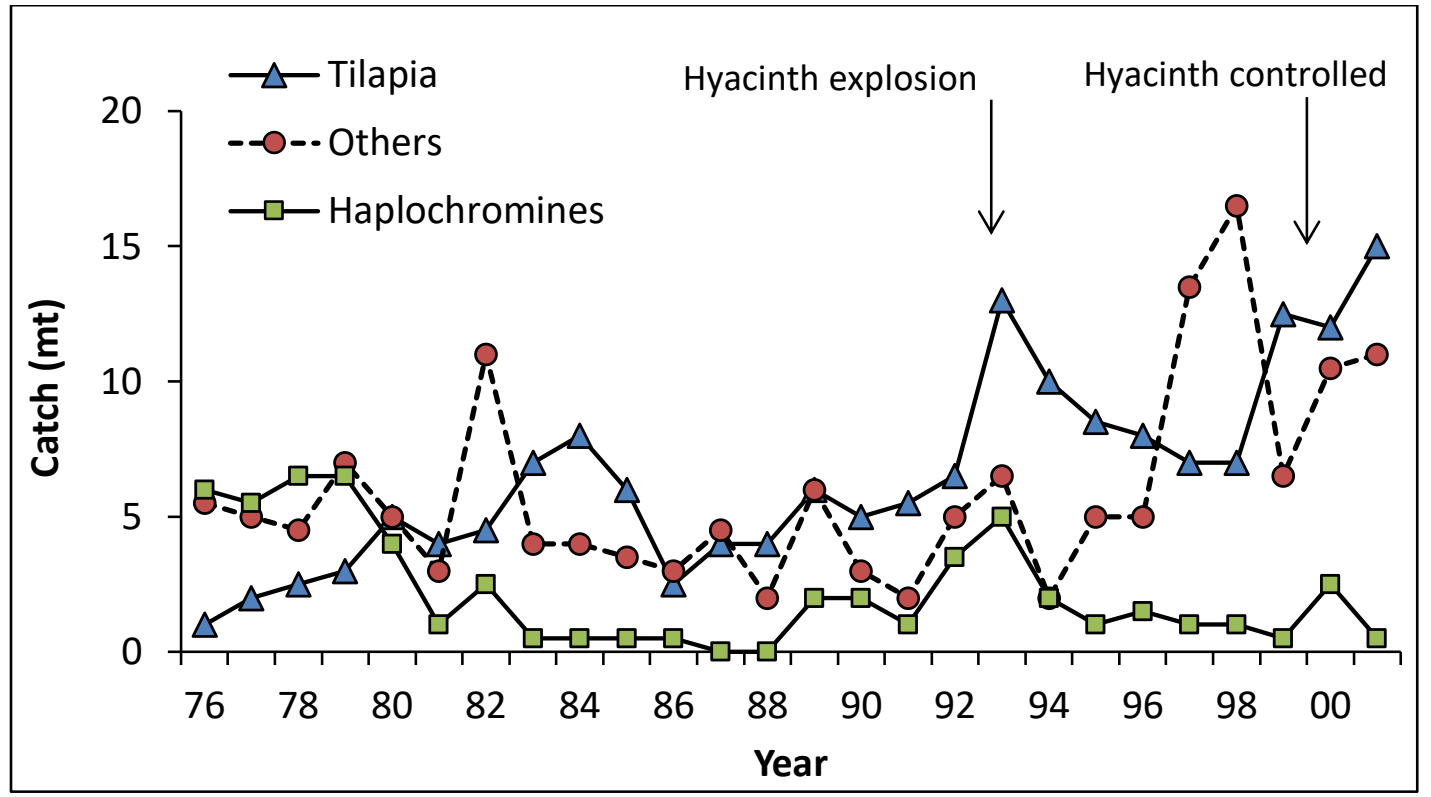

Figure 3: Catches of haplochromines, tilapia and other species (Clarias, Protopterus) in Lake Victoria during hyacinth infestation 1976 to 2001 (data adapted from Njiru et al. 2005).

\section{Catch trends}

Haplochromine cichlids were the dominant fish in Lake Victoria during the 1970s, forming the major prey item for the introduced Nile perch (Figure 2). However, from 1970s to 1989 there was a boom in Nile perch abundance that coincided with the decline of the endemic haplochromine cichlid species (Figure 4). The reduction in cichlid catches was attributed 
primarily to predation by Nile perch and overfishing (Witte et al. 1999), hybridization trigged by pollution (Seehausen et al. 1997) and eutrophication (Kolding et al. 2008). After depletion of the haplochromine stocks in Lake Victoria at the end of the 1980s, Nile perch shifted to feeding on shrimp, Caridina nilotica, juvenile Nile Perch, O. niloticus and R. argentea (Figure 2). The catches of other species including Clarias and Protopterus declined, while O. niloticus instead increased and formed a peak during 2005, following the decline in Nile perch catches (Figure 4). From 1989, Nile perch catches began declining, and some haplochromine cichlids re-appeared in 2000 as shown in figure 4, also reported by other authors (Balirwa et al. 2003). Accordingly, haplochromines again became the main prey items for Nile perch in Lake Victoria (Figure 2). Oreochromis niloticus has been able to establish in Lake Victoria, currently forming the third commercially important species after the introduced Nile perch, L. niloticus and a native cyprinid $R$. argentea, whereas other tilapias are extinct or are occasionally caught in the lake.

According to Marshall et al (2019), in the Ugandan waters, the Nile perch catch rate rose from $0.5 \mathrm{~kg} \cdot \mathrm{h}^{-1}$ in the $1969-1971$ trawls to $3.5 \mathrm{~kg} \cdot \mathrm{h}^{-1}$ in 1981 (Table 1). This was followed by an increase from 3.5 to $234.7 \mathrm{~kg} \cdot \mathrm{h}^{-1}$ between 1981 and 1985 . The haplochromine biomass rose slightly between $1969-1971$ and 1981 , but fell from $391.7 \mathrm{~kg} \cdot \mathrm{h}^{-1}$ in 1981 to $264.6 \mathrm{~kg} \cdot \mathrm{h}^{-1}$ in 1983 , followed by a collapse to zero in 1986. The biomass of other species declined from 1982 onwards, with the most rapid collapse beginning in 1984 when the biomass of Nile perch exceeded that of all other species. Direct evidence of predation by Nile perch on the haplochromines provided strong evidence for a role of this species in the extinction of many species (Kishe-Machumu et al. 2012), but the impact of the tilapiines on the native species is still largely unclear. This is partly due to the many other changes taking place in the system over the same timescale, including widespread eutrophication and extensive fisheries operations (Verschuren et al. 2002; Hecky et al. 2010).

Debate on the contribution of Nile perch to the demise of Lake Victoria's 500+ endemic haplochromine cichlids centers around the "top-down" and "bottom-up" hypotheses (Marshall et al. 2019). The former suggests Nile perch destroyed the haplochromines, causing the disruption of food chains and nutrient cycling and so initiating the accelerated eutrophication of the lake. The latter proposes that haplochromines suppressed Nile perch by preying on its eggs and fry or competing with juveniles for food. A recent paper by Marshall et al (2019) argued that 
accelerated eutrophication caused by a climatic event led to their collapse, allowing Nile perch to explode. A review of the impacts of eutrophication on Lake Victoria fishes concluded that the haplochromine decline was caused by Nile perch (Witte et al. 2005), but it was later suggested that it was not possible to separate the effects of Nile perch and eutrophication since both occurred in the same time period (Witte et al., 2013). Other authors have argued that "bottom up" influences are a more valid explanation for the changes in Lake Victoria, with Nile perch being just one of a multiplicity of stressors (Kolding et al. 2008; Hecky et al. 2010)

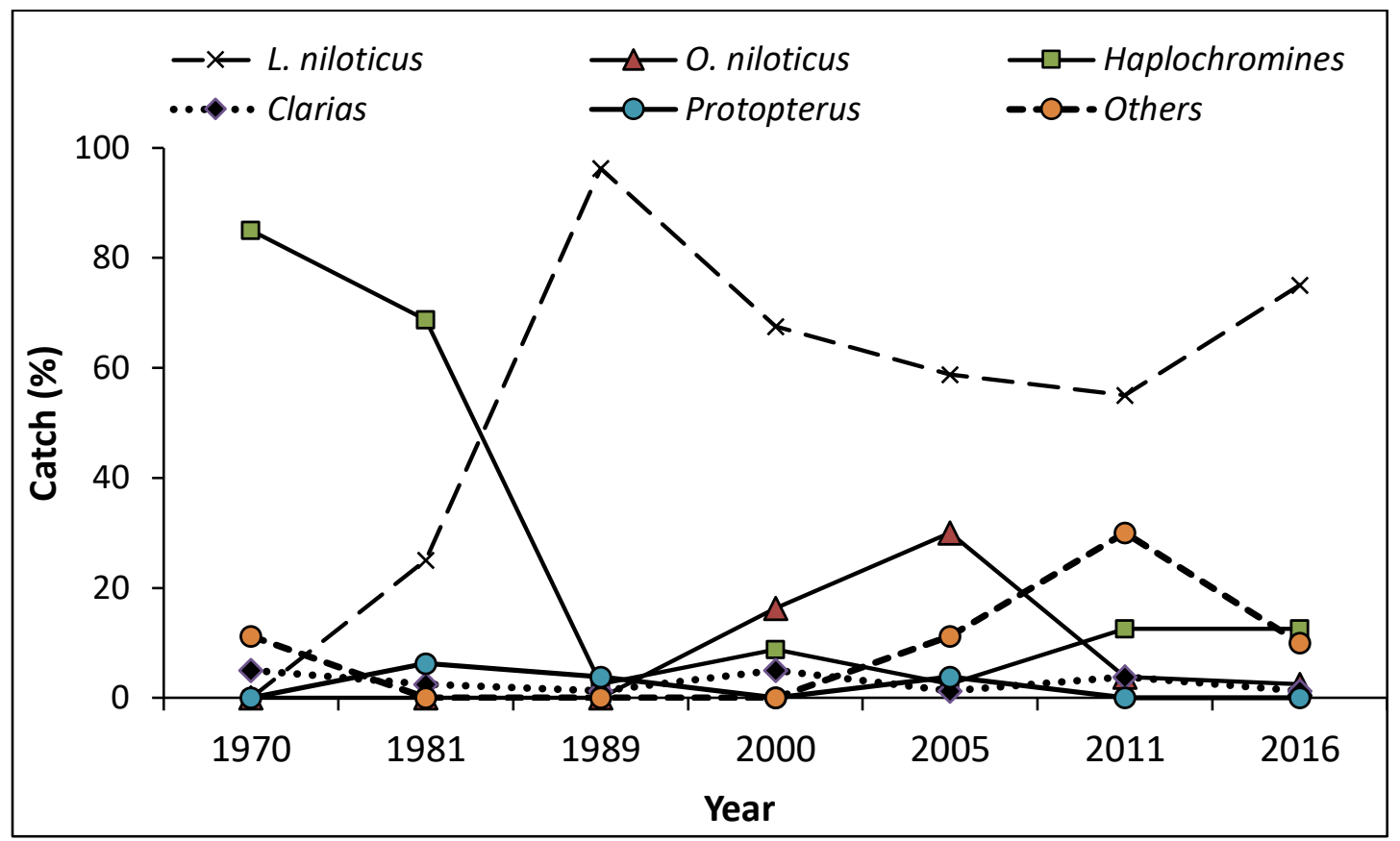

Figure 4: Trends in catches of some major commercial fish species in Lake Victoria 1970 to 2016 (data adapted from Njiru et al. 2018). 
Table 1: The relative abundance $\left(\mathrm{kg} \cdot \mathrm{h}^{-1}\right)$ of demersal fish species caught in bottom trawls in the Ugandan waters of Lake Victoria (Adapted from Marshall et al. 2019)

\begin{tabular}{llllllll}
\hline & $1969-1971$ & 1981 & 1982 & 1983 & 1984 & 1985 & 1986 \\
\hline Haplochromines spp & 327.4 & 391.7 & 295.7 & 264.6 & 113.9 & 17.8 & - \\
Lates niloticus & 0.5 & 3.5 & 45.3 & 54.3 & 140.2 & 234.7 & 80.1 \\
Oreochromis niloticus & 0.9 & 12.2 & 7.3 & 5.2 & 1.8 & 5.0 & 7.1 \\
Oreochromis esculentus & 2.6 & 0.5 & 0.1 & - & - & - & - \\
Oreochromis variabilis & 0.6 & 5.6 & 2.5 & 0.9 & - & - & - \\
Bagrus docmak & 23.5 & 9.0 & 9.3 & 11.3 & 4.3 & 1.5 & 0.3 \\
Clarias gariepinus & 17.3 & 14.4 & 8.0 & 4.4 & 1.8 & 0.1 & - \\
Protopterus aethiopicus & 5.8 & 4.9 & 0.1 & 0.8 & 0.6 & 0.1 & - \\
Synodontis spp. & 15.4 & 2.9 & 0.5 & 04 & 0.2 & 0.1 & - \\
Other species & 0.9 & 0.2 & 1.6 & 4.7 & 0.3 & 0.3 & - \\
Total & 394.9 & 444.9 & 370.4 & 346.6 & 264.3 & 259.6 & 87.5 \\
\hline
\end{tabular}

\section{Lake Naivasha Fishery}

\section{Fish introductions}

Lake Naivasha is a freshwater body in Kenya. The lake fishery provides source of livelihood to about 650,000 people living around it and other cities in Kenya. The fishery of Lake Naivasha is based mainly on the introduced species namely Common carp, Cyprinus carpio, Nile tilapia, Oreochromis niloticus, blue spotted tilapia, Oreochromis leucostictus, red-belly tilapia, Coptodon zillii, largemouth bass, Micropterus salmoides and African sharptooth catfish, Clarias gariepinus (Njiru et al. 2017). Before the introductions, Lake Naivasha originally contained only the endemic black lampeye Micropanchax antinorii that was last recorded in 1962 and is believed to have gone extinct through predation pressure from the introduced $M$. salmoides (Muchiri \& Hickley 1991).

Various fish species including tilapiines have been introduced into Lake Naivasha over time (Hickley et al. 2015). Coptodon zillii and O. leucostictus were introduced from Lake Victoria into Lake Naivasha in 1956 to establish a population for commercial exploitation. Oreochromis niloticus was first introduced into Lake Naivasha in 1967 in order to diversify and boost the dwindling fishery of the lake (Kundu et al. 2010). However, it disappeared from the lake in 1971 (Gozlan et al. 2010), but was later reintroduced during 2011 and 2014 (Waithaka et al.2020). Introduction of $C$. carpio in Lake Naivasha was accidental, with fish possibly having escaped 
from fish farms adjacent to River Malewa, the main inflow into the lake, and into which $C$. carpio fingerings had been stocked in 1997 (Ojuok et al.2007).

\section{Catch trends}

From 1992 until 2000, Lake Naivasha was dominated by tilapiine fishery, mostly the exotic species, O. leucostictus with minor contribution from C. zillii (Figure 5). In 2001 the lake fishery was closed in bid to increase catches especially of $M$. salmoides and $C$. zillii which were dwindling. After reopening of the fishery in 2002, C. carpio began to appear in catches and since then it has increased and dominated the fishery of the lake (Hickley et al. 2015). This occurred shortly after its introduction into the lake in 1999. From 2011 to 2015 onwards, C. carpio has been the dominant species in the lake, while other species including O. leucostictus, O. niloticus, C. zillii, M. salmoides and C. gariepinus continued to decline (Figure 6). The establishment and sustainability of $C$. carpio in Lake Naivasha could be attributed to its life history traits of rapid growth and high fecundity as reported by Ojuok et al (2007) and Oyugi et al (2011). The species is hardy, tolerant of degraded aquatic environment and thrives well in turbid waters (Scott \& Crossman 1973).

The increase in C. carpio could have several detrimental effects on other Lake Naivasha fishery (Hickley et al. 2004). It feeds by uprooting aquatic plants, thus increasing water turbidity that in turn reduces light availability for the productivity of phytoplankton and submergent macrophytes. (Ojuok et al.2007). Reduction in algae and macrophytes threaten the food base for phytoplanktivorous $O$. leucostictus and herbivorous $C$. zillii. Disturbance of the lake bottoms by C. carpio would seriously affect $C$. zillii which lays adhesive eggs on the lake bottoms with pebbles or sand and with abundant vegetation (Hickley \& Harper 2002). Breeding of $M$. salmoides and $O$. leucostictus, which build their nests on muddy bottoms of shallow water are also adversely affected by the feeding behaviour of $C$. carpio. The $C$. carpio and $C$. zillii both lay sticky eggs, thus compete for the substratum to attach their eggs (Petr 2000). The C. carpio also prey on juveniles and eggs of the other species in the lake (Ojuok et al. 2007). 


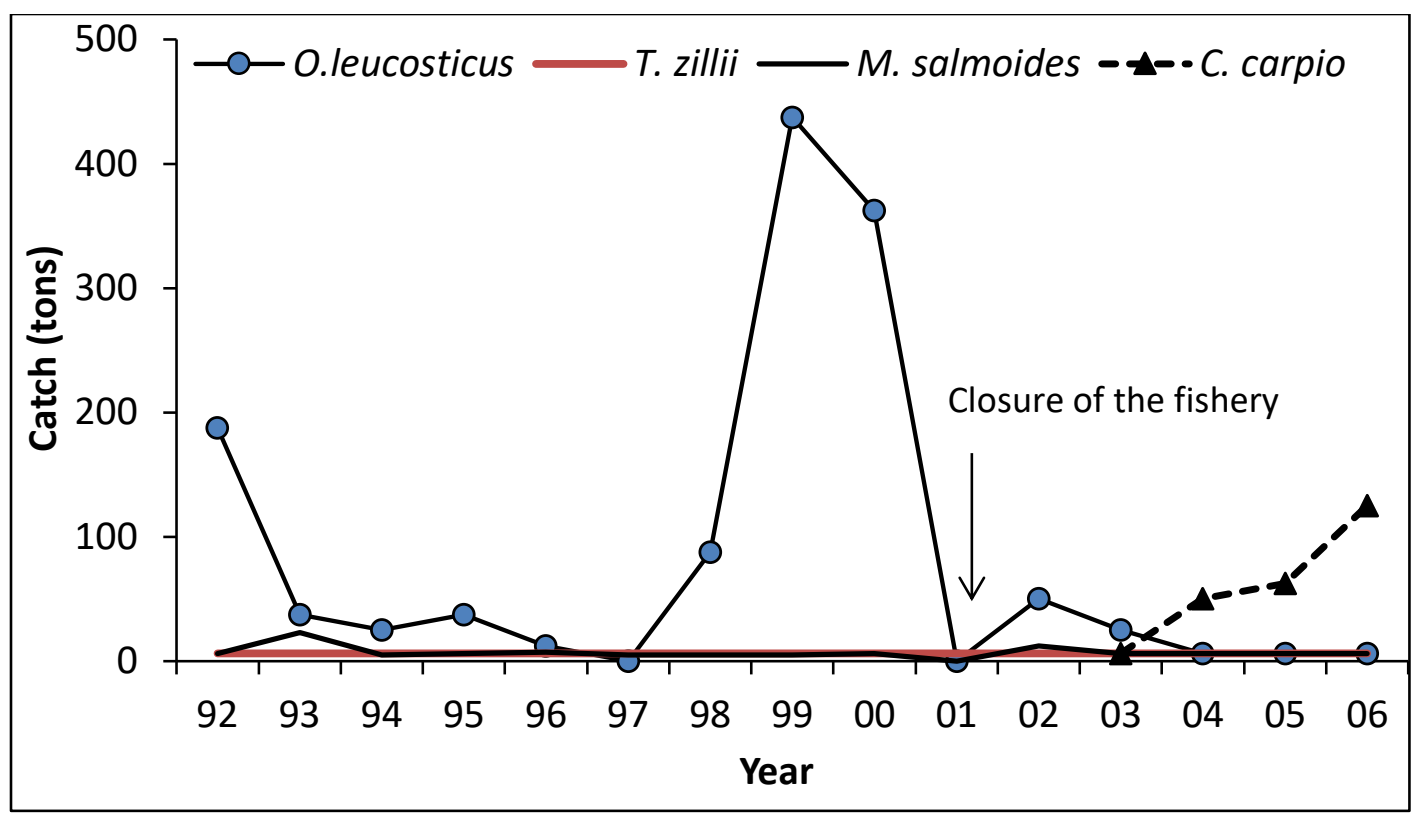

Figure 5: Trends in catches of the major commercial fish species in Lake Naivasha 1992 to 2006 (data adapted from Ojuok et al. 2007).

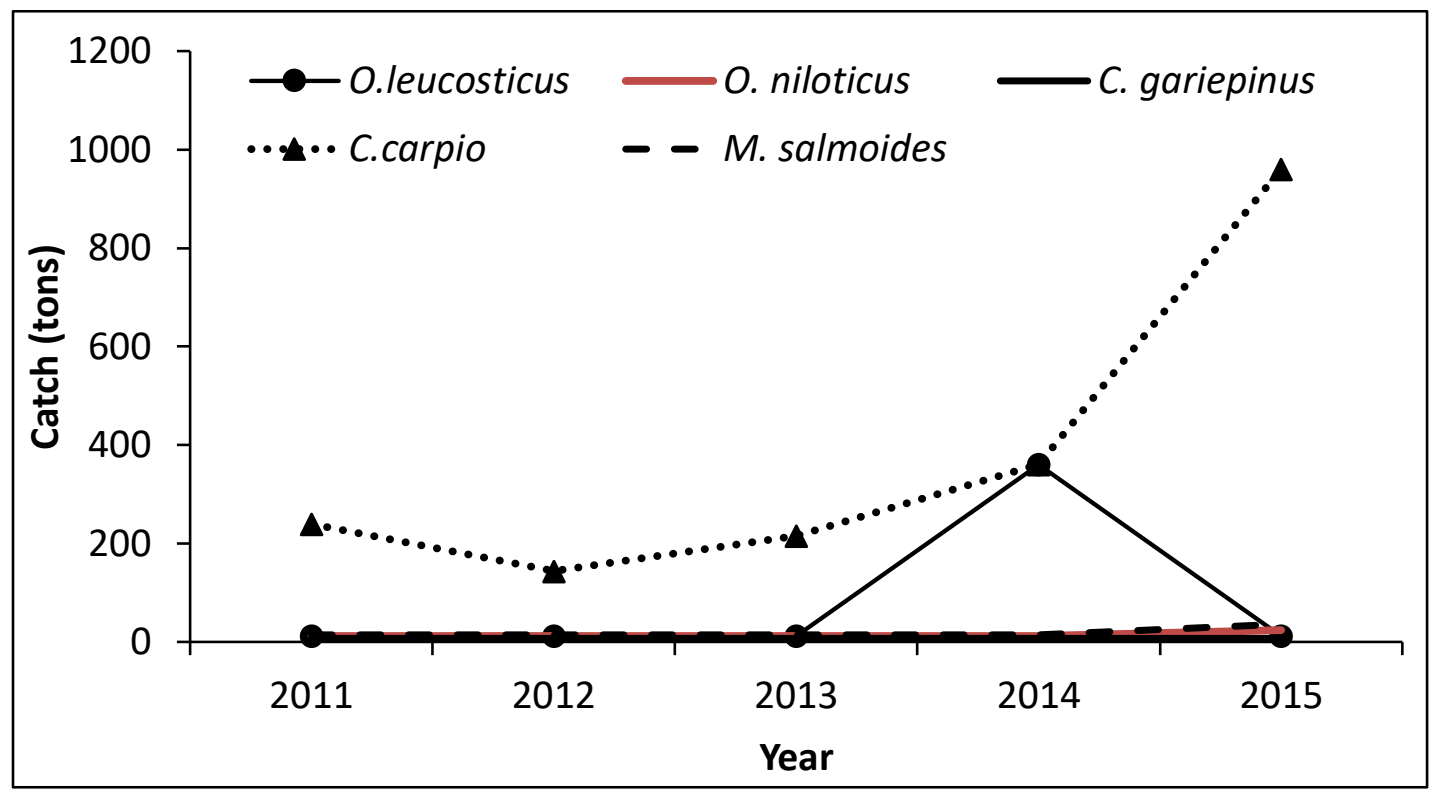

Figure 6: Trends in catches of the major commercial fish species in Lake Naivasha 2011 to 2015 (data adapted from Njiru et al. 2017). 


\section{Biological and population parameters}

Data on sex ratio, condition factor and size at first maturity of O. niloticus and O. leucostictus in lakes Victoria and Naivasha are available from 1998 to 2017 (Table 2). The sex ratio showed that males are predominant over females in both lakes. The authors suggest male tilapias usually tend to grow faster and attain bigger sizes than their female counterparts, thus increasing their probability of capture (Njiru et al. 2006). The size at first maturity of the female O. niloticus in Lake Victoria has declined from $31.0 \mathrm{~cm}$ TL (1998) to $26.0 \mathrm{~cm}$ TL (2015). Similarly, female $O$. leucostictus in Lake Naivasha tend to mature at smaller size $(21.0 \mathrm{~cm}$ TL) as reported by Laurent et al (2020). The reduction in size at maturity could be a strategy to maximize reproductive success in response to overexploitation of fish stocks (Njiru et al. 2006; Yongo et al. 2018). The O. niloticus exhibited isometric growth $(b=3)$ in Lake Victoria (Yongo et al. 2018), whereas it had negative allometric growth pattern $(b<3)$ in Lake Naivasha (Waithaka et al. 2020). Fish can attain either isometric growth, negative allometric growth or positive allometric growth. Isometric growth is associated with no change of body shape as an organism grows. Negative allometric growth implies the fish becomes more slender as it increase in weight while positive allometric growth implies the fish becomes relatively stouter or deeper-bodied as it increases in length (Riedel et al. 2007). The growth and condition factor of fish can be affected by a number of factors such as stress, sex, season, food availability, and other water quality parameters (Mutethya et al. 2020). Knowledge of length-weight relationship is important in studying fish biology.

The different variables of changes in population parameters of O. niloticus and O. leucostictus in Lake Victoria and Naivasha between 1985 and 2017 are shown in Table 3. Analysis of population parameters shows that growth coefficient $(K)$, total mortality $(Z)$, fishing mortality $(F)$, natural mortality $(M)$ and exploitation rate $(E)$ have increased, while asymptotic length $(L \infty)$ has decreased. Lake Victoria fishery is open access, and an increase in fishing boats, fishers, gears and the use of illegal gears have led to overexploitation (Cowx et al. 2003; Njiru et al. 2008). These changes in biological and population characteristics of $O$. niloticus could be tactics to maximize survival and reproductive success in response to intense fishing and changing ecological conditions (Njiru et al. 2006; Yongo et al. 2018) Fishing mortality $(F)$ is primarily induced by the fishing effects on the stocks. However, natural fish mortality $(M)$ is caused by 
factors not associated with fishing; predation, competition, cannibalism, diseases, spawning stress, starvation and pollution stress (Yongo \& Outa 2016).

Table 2: Parameters of sex ratio, exponent of the length-weight relationship $(b)$, condition factor (K) and maturity of O. niloticus and O. leucostictus in Lakes Victoria and Naivasha 1998 to 2017.

\begin{tabular}{|c|c|c|c|c|c|c|c|}
\hline Lake \& period & Species & $\begin{array}{l}\text { sex ratio } \\
(\mathrm{M}: \mathrm{F})\end{array}$ & $\begin{array}{l}\text { Slope } \\
b\end{array}$ & $\begin{array}{l}\text { Condition } \\
K\end{array}$ & $\begin{array}{l}\mathrm{Lm}_{50} \\
\text { males }\end{array}$ & $\begin{array}{l}\mathrm{Lm}_{50} \\
\text { females }\end{array}$ & Source \\
\hline Victoria-1998/99 & O. niloticus & $1.49: 1.0$ & 3.14 & 0.71 & 34.0 & 31.0 & Ojuok et al (2000) \\
\hline Victoria-1998/00 & O. niloticus & $1.42: 1.0$ & $3.1-3.3$ & $0.92-1.07$ & 35.0 & 31.0 & Njiru et al (2006) \\
\hline Naivasha-2013/14 & O. niloticus & 2.24:1.0 & 2.3 & 2.46 & 17.7 & 18.0 & Outa et al (2014) \\
\hline Victoria-2014/15 & O. niloticus & 1.20:1.0 & 3.0 & $1.02-1.04$ & 31.0 & 26.0 & Yongo et al (2018) \\
\hline Naivasha-2017 & O. niloticus & $2.21: 1.0$ & 2.86 & 1.01 & 28.0 & 28.0 & Waithaka et al (2020) \\
\hline Naivasha-2017 & O. leucostictus & 2.19:1.0 & 2.33 & 1.04 & 26.0 & 21.0 & Laurent et al (2020) \\
\hline
\end{tabular}

Table 3: Population parameters of $O$. niloticus and $O$. leucostictus in Lakes Victoria and Naivasha 1985 to 2017

\begin{tabular}{llllllllll}
\hline & & $L \infty$ & $K$ & $\emptyset$ & $Z$ & $M$ & $F$ & $E$ & \\
Lake \& Period & Species & $c m T L$ & $y r^{-1}$ & & $y r^{-1}$ & $y r^{-1}$ & $y r^{-1}$ & & Source \\
\hline Victoria-1985/86 & O. niloticus & 64.60 & 0.25 & 3.03 & 0.82 & 0.54 & 0.28 & 0.34 & Getabu (1992) \\
Victoria-1989/90 & O. niloticus & 63.10 & 0.35 & 3.16 & 1.71 & 0.72 & 0.99 & 0.58 & Dache (1994) \\
Victoria-1995 & O. leucostictus & 38.0 & 0.48 & 2.80 & 3.50 & 0.19 & 2.6 & 0.74 & Njiru \& Ojuok (1997) \\
Victoria-1998/00 & O. niloticus & 59.5 & 0.66 & & 2.42 & 1.07 & 1.34 & 0.55 & Njiru (2003) \\
Victoria-1998/00 & O. niloticus & 58.8 & 0.56 & 3.14 & 1.92 & 1.00 & 1.32 & 0.55 & Njiru (2007) \\
Victoria-2007 & O. niloticus & 53.9 & 0.50 & & 2.83 & & 1.92 & 0.68 & Njiru et al (2008) \\
Victoria-2014/15 & O. niloticus & 46.24 & 0.69 & 3.14 & 2.18 & 1.14 & 1.05 & 0.46 & Yongo \& Outa (2016) \\
Naivasha-2017 & O. niloticus & 42.0 & 0.21 & 2.57 & 0.80 & 0.55 & 0.26 & 0.32 & Waithaka et al (2020) \\
\hline
\end{tabular}

\section{Challenges to Lake Victoria Ecosystem}

Management of Lake Victoria fisheries has faced various challenges. The lake's ecosystem has been severely affected by human activities and environmental changes, including the introduction of exotic species, invasion of water hyacinth, climate change, over-exploitation, pollution and eutrophication (Kolding et al. 2008). Increased human population has led to the encroachment of swamps surrounding the lake, clearing land for settlements and agriculture. Swamps clearance contributed to the decline in wetland areas thus, reduced the nursery grounds 
for O. esculentus and the feeding niche for the introduced C. zillii (Njiru et al. 2008). Poor agricultural practices and deforestation caused land degradation and soil erosion that have accelerated nutrient loading and agro-chemical input into the water systems (Mugidde et al. 2005). Nutrient input into the lake also come from domestic and industrial effluents. Increased pollution has caused the lake's phytoplankton community to be dominated by unpalatable and toxic cyanobacteria, Microcystis (Lung'ayia et al. 2000). The algal bloom and increase in cyanobacteria is due to increased nutrient rich sewage effluents and agricultural runoffs. Algal blooms can cause fish mortality due to the anoxic conditions.

Several studies have showed that the rapid growth and establishment of water hyacinth, Eichhornia crassipes in Lake Victoria was due to increased nutrients levels (Mugidde et al., 2005; Njiru et al. 2002; Ogari and van der Knaap, 2002). Water hyacinth has caused negative environmental and socio-economic effects on the lake interfering with lake transport, water quality and fisheries. Shading of the water by water hyacinth curtails phytoplankton photosynthesis, thus limits oxygen production. Microbial breakdown of the decaying hyacinth also uses the available oxygen. Water hyacinth mats decrease dissolved oxygen concentrations beneath by preventing the transfer of oxygen from air to water surface. The oxygen can be reduced to very low levels that it causes massive fish mortality (Yongo et al. 2017b). Water hyacinth however, led to the recovery of those native fishes more tolerant to hypoxia conditions such as catfishes, haplochromines and P. aethiopicus (Njiru et al. 2002). This is because $P$. aethiopicus is obligatory air breather, while C. gariepinus has an accessory organ that enables it to extract oxygen from the air in waters with low concentration.

Climate change and deforestation have also led to a reduction in precipitation in the Lake Basin (Sutcliffe and Petersen, 2007). These changes have an ecological impact on lake fisheries, including the reduction of fish habitats due to declining lake water levels. In the event of heavy precipitation, severe erosion, increased siltation and run off lead to elements in the lake that can be harmful to fish health. Thermal stratification regulates the balance between dissolved oxygen and nutrients from deeper water depths at the surface of the water layers, as well as the development of low oxygen concentrations, and the distribution of plankton and fish. Seasonal anoxic conditions and the accumulation of toxic compounds result in the movement of lesstolerant natives fish species into the oxygenated surface waters, where they are subsequently 
exposed to heavy predation by Nile perch, and possibly a higher fishing mortality (Witte et al. 1992; Getabu et al. 2002).

The decline in fish catches and changes in the fish population parameters in Lake Victoria have been attributed to increased capacity, leading to increased numbers of fishers, boats and illegal gears (Njiru et al. 2018). Fishers have resorted to the use of cast netting, smaller-mesh-sized gillnets and beach seines. When used in shallow areas, seines capture immature fish, disrupt spawners and destroy substratum on which primary productivity is dependent (Njiru et al. 2018). Intensive fishing across the rivers and river mouths, the use of highly efficient fishing gears (e.g. monofilaments and small-size gillnets) have prevented recovery of the once prominent potamodromous fishery of Labeo, Barbus, Synodontis spp. and mormyrid fishes (Witte et al. 1992). Poverty has been reported as one of the stimulus to overfishing in Lake Victoria (Njiru et al. 2018).

\section{Challenges to Lake Naivasha Ecosystem}

The lake Naivasha ecosystem has been faced with several challenges that have negatively impacted on the fish stocks. Some of these problems include intense fishing, exotic species introductions, water abstraction, lake level fluctuations, wetland utilization, and eutrophication and land degradation. There is rampant use of illegal gears such as seine and monofilament nets. There is also use of gillnets of 3.5" and below to target the smaller sized O. niloticus, $O$. leucosticus and C. zillii (Njiru et al. 2017). The fishers regularly used illegal gears to fish in shallow areas that act as breeding and nursery grounds for most fishes in the lake. The growth in human population has increased domestic discharge into the lake causing pollution. High volumes of fertilizers, pesticides and effluents produced by the Naivasha floricultural industry further cause lake pollution. The population growth has caused increased degradation of the lake catchment with the cutting down of trees to provide for firewood, charcoal and timber for construction (Mireri 2005). Reduction of the wetland swamp is attributed to direct human clearance, lowering of the lake waters, grazing by herbivores such zebra, buffalos, cattle, and Procambarus clarkia (Harper and Mavuti 2004).

The wetland degradation and subsequent eutrophication of the lake further reduces suitable areas for fish to breed and replenish the declining stocks (Njiru et al. 2017). The reduction in water 
levels in the lake is mostly associated with the use of water to irrigate horticultural farms, though it may also be related to deforestation in the catchment area which has led to lower amount of rainfall. There has been an adverse impact on the interactions between the multiple exotic species in the lake. The dominance of $C$. carpio and the reduction of the other species in the lake may be attributed to changes in water quality and the ecosystem. Carp feeding mode uproots aquatic plants, stirs the sediments at the bottom, increases water suspended solids and affects water turbidity (Parkos et al. 2003). Increased turbidity decreases light penetration that is important for photosynthesis of submergent plants and phytoplankton. Decreased phytoplankton and aquatic plants reduces food-base for phytoplanktivorous fishes such as $O$. leucosticus and herbivorous C. zillii (Njiru et al. 2017).

\section{Management strategies in Lake Victoria}

Considering the lakes` fishery the three riparian countries, under the auspices of the East African Community, formed the Lake Victoria Fisheries Organization (LVFO) in 1994, in order to coordinate the management and conservation of the Lake and its basin. The three countries have subsequently established the Lake Victoria Basin Commission to coordinate environmental issues in the lake basin (Njiru et al. 2008). Lake Victoria Basin Commission (LVBC) coordinates several projects focusing on the health of the Lake Victoria ecosystem. The Lake Victoria Environmental Management Project (LVEMP), for example, it is one of the major projects utilizing a holistic approach to manage the lake and its basin with stakeholders involvement (Njiru et al. 2008). Several closed areas have been established in Lake Victoria to protect the fishery during their spawning periods (Njiru et al. 2005; Mkumbo 2002). The closed areas need to be extended to river mouths, riverine environments and adjoining flood plains to also protect potamodromous fishes. The Kenyan government has indeed promoted aquaculture to increase food production in order to minimize fishing pressure. Laws regarding the treatment of effluents in the three countries harmonized and enforce regulations to protect the lake and its resources.

The riparian land around Lake Naivasha is under the custodian of a Non-Governmental Organization (NGO), the Lake Naivasha Riparian Association (LNRA) that works through a committee representing stakeholders with an interest in the lake (Ballot et al. 2009). The goal of the committee is to achieve sustainable utilization of the lake resources, including the fisheries. Imarisha program is a Public-Private Partnership (PPP) initiative to mitigate destruction 
occurring around Lake Naivasha Basin, safeguard sustainability development, secure investments and improve community livelihoods (Njiru et al. 2017). The anticipated outcomes of these initiatives include: "wise use" of Lake Naivasha resources and its riparian zone. Imarisha Naivasha has initiated several projects in collaboration with their partners towards realizing its mandate. These include improvement of fisheries infrastructure such as landing sites. Imarisha Naivasha Water stewardship Project (INWaSP) objective is to restore the lake basin through programs such as reforestation in order to reduce erosion and nutrients loading into the lake so as to improve the lake's health and maintain a conducive environment for the fisheries.

Management of fisheries in Kenya has been a top-down approach led by the central government with little involvement of stakeholders (Kundu et al. 2010,Nunan 2010). It was recognized that for better management of the fisheries, a participatory management approach that is coupled with law enforcement was necessary (Kundu et al. 2010). It is in this context that the Kenyan government adopted bottom-up co-management framework and brought in stakeholders through community involvement by forming the Beach Management Units (BMUs). To protect the fisheries and biodiversity in these lakes, there is a need to limit access of the lake to fishing, and to eliminate illegal fishing gears. Complete eradication of illegal gears and limited access can be achieved by enforcement, surveillance and licensing/permits of boats, fishers and gears through the BMUs.

To conclude, here we report that the tilapiine species in lakes Victoria and Naivasha ecosystems have shown declining trends in catches over time since their introduction. Similarly, the biological and population parameters of the tilapiines have changed greatly over time. These observations are attributed to the effects of the increasing fishing pressure, deteriorating environmental conditions and the introduction of non-native species. This therefore, calls for a need to improve on the management measures applicable in the two lake ecosystems, such as fishing effort control, pollution control and protecting the surrounding wetland from degradation. Further work is needed to carry out a stock assessment of the lakes to inform fisheries management decisions 


\section{References}

Agembe S, Yongo E, Masese F, Njiru J, Manyala J, Ojwang W.,2018, Shifts in the food of Nile perch (Lates niloticus) in Lake Victoria. Lake. Reser: Res. Managt, 1-5.

Balirwa J.S, Chapman C.A, Chapman L.J, Cowx I.G, Heheb K., 2003, Biodiversity and fishery sustainability in the Lake Victoria basin: an unexpected marriage? Bio. Sci. 53, 703-715.

Balirwa J.S., 1998, Lake Victoria wetlands and the ecology of the Nile tilapia, Oreochromis niloticus (L.). PhD thesis, University of Wageningen, A.A. Balkema, Rotterdam.

Ballot A, Kotut K, Novelo E, Krienitz L. 2009, Changes of phytoplankton communities in Lakes Naivasha and Oloidien, examples of degradation and salinization of lakes in the Kenyan Rift Valley. Hydrobiologia 632: 359-63.

Cowx I.G., Van der Knaap M., Muhoozi L.I., Othina A., 2003, Improving fishery catch statistics for Lake Victoria. Aqu. Ecosy. Health Managt. 6, 299-310.

Dache S. A. O., 1994, Observations on the fisheries, growth and mortality of Oreochromis niloticus (tilapia) in Nyanza Gulf of Lake Victoria. In: Proceedings, Second Regional Seminar on Recent Trends of Research on Lake Victoria Fisheries, 25-27 Sept. 1994, Kisumu, Kenya (eds E. Okemwa, E. Wakwabi \& A. Getabu) pp. 59-65. ICIPE Press, Nairobi, Kenya. from Lake Naivasha, Kenya. Afr. J. Trap. Hydrobiol. Fish. 7, 17-21

Dunz and Schliewen 2013 Molecular phylogeny and revised classification of haplotilapiine cichlid fishes formely referred to as tilapia. Molecular phylogenetics and Evolution,68(1):64-80 zoological Record volume 149

Getabu A., 1992, Growth parameters and total mortality in Oreochromis niloticus (Linnaeus) from Nyanza Gulf, Lake Victoria. Hydrobiologia. 232, 91-97.

Getabu A., Tumwebaze R. \& Maclennan D. N., 2002. Spatial and temporal changes in the fish populations of Lake Victoria. Aquat. Living Resour. 16, 159-65.

Goudswaard, P. C., F. Witte \& E. F. B. Katunzi, (2002). The tilapiine fish stock of Lake Victoria before and after the Nile perch upsurge. Journal of Fish Biology 60: 838-856.

Gozlan R.E, Britton J.R, Cowx I, Copp G.H., 2010, Current knowledge on non-native freshwater fish introductions. J. Fish. Biol. 76(4), 751-786.

Gu, D.E, Fan Dong Yu, Meng Xu, Hui Wei, Xi Dong Mu, Du Luo, Ye Xin Yang, Zhi Pan \& Yin Chang Hu. (2018). Temperature effects on the distribution of two invasive tilapia species 
(Tilapia zillii and Oreochromis niloticus) in the rivers of South China, Journal of Freshwater Ecology, 33:1, 511-524.

Harper DM \& Mavuti K.M. (2004). Lake Naivasha, Kenya: Ecohydrology to guide the management of a tropical protected area. Ecohydrology Hydrobiology 4: 287-305.

Hecky, R. E., R. Mugidde, P. S. Ramlal, M. R. Talbot \& G.W. Kling (2010): Multiple stressors cause rapid ecosystem change in Lake Victoria. Freshwater Biology 55: 19-42.

Hickley P, Bailey R, Harper D. M, Kundu R, Muchiri M, North R, Taylor, A., 2002, The status and future of the Lake Naivasha fishery, Kenya. Hydrobiol. 488, 181-190.

Hickley P, Britton J, Macharia S, Muchiri S.M, Boar R.R.,2015, The introduced species fishery of Lake Naivasha, Kenya: ecological impact vs socioeconomic benefits. Fish. Managt. Ecol. 22(4), 326-36. [http://dx.doi.org/10.1111/fme.12130]

Hickley P, Harper D. M., 2002, Fish community and habitat changes in the artificially stocked fishery of Lake Naivasha, Kenya. In Cowx, I. G. (ed.), Management \& Ecology of Lake and Reservoir Fisheries. BSP, Oxford: 242- 254.

Hickley P, Muchiri M, Gichuru N, Britton R, Harper D, Adams C, Boar R., 2004, Habitat degradation and subsequent fishery collapse in Lakes Naivasha and Baringo, Kenya. Ecohydrol. Hydrobiol.4,503 - 517. https://doi.org/10.1007/s10750-018-3597-9

Johnson T.C, Kelts K, Odada E., 2000, The Holocene history of Lake Victoria. Ambio.29 (10), 214.

Kishe-Machumu, M. A., F. Witte, J. H. Wanink \& E. F. Katunzi, (2012): The diet of Nile perch, Lates niloticus (L.) after resurgence of haplochromine cichlids in the Mwanza Gulf of Lake Victoria. Hydrobiologia 682: 111-119.

Kolding J, Van Zwieten P, Mkumbo O, Silsbe G. M, Hecky R. E., 2008, Are the Lake Victoria fisheries threatened by exploitation or eutrophication? Towards an ecosystem based approach to management. In G. Bianchi, \& H. R. Skjoldal (Eds.), The ecosystem approach to fisheries international (pp. 309-354). Rome, Italy: CAB. https://doi.org/10.1079/9781845934149.0000

Kundu R, Aura C.M, Muchiri M, Njiru M, Ojuok J.E., 2010, Difficulties of fishing at Lake Naivasha, Kenya: is community participation in Management the Solution? Lake. Reser: Res. Managt. 15(1), 15-23.[http://dx.doi.org/10.1111/j.14401770.2010.00419.x] 
Laurent, C., Yongo, E., Waithaka, E., \& Mutethya, E., 2020. Analysis of some biological aspects of the Blue-spotted tilapia, Oreochromis leucostictus (Trewavas, 1933) in Lake Naivasha, Kenya. https://doi.org/10.31219/osf.io/6xf7j

Loiselle P.V., 1997. The natural history and aquarium husbandry of the Mbiru (Oreochromis variabilis) (Boulenger 1906). Aquarium Frontiers and Fancy Publications Inc. Animal Network.

Lowe-McConnell, R.H., 1955, The fecundity of tilapia species. E. Afr. Agri. J. 11, 45-52.

Lung'ayia H. B. O., M’Harzi A., Tackx M., Gichuki J. \& Symoens J. J.,2000. Phytoplankton community structure and environment in the Kenyan waters of Lake Victoria. Freshwat. Biol. 43, 529-43.

Mireri, C. (2005). Proceedings FWU topics of integrated watershed management. Challenges Facing the Conservation of Lake Naivasha, Kenya GTZ Dar es Salaam; 3: 89-98.

Muchiri S.M., Hickley P., 1991, The fishery of Lake Naivasha, Kenya. In: Cowx IG, Ed. Catch effort sampling strategies: their application in freshwater fisheries management. Oxford: Fishing News Books, BSP Press, pp. 382-92.

Mugidde R., Gichuki J., Rutagemwa D., Ndawula L. \& Matovu X., 2005. Status of water quality and its implication on the fishery production. In: The State of the Fisheries Resources of Lake Victoria and Their Management. Proceedings of the Regional Stakeholders' Conference, Lake Victoria Fisheries Organization Secretariat, Jinja, Uganda pp. 106 -112

Mutethya, E., Okoth, S \& Yongo, E. (2020). Biological aspects of Schilbe intermedius (Ruppell, 1832) in the Nyanza Gulf of Lake Victoria, Kenya. Lakes and Reservoirs: Research and Management 1-5.

Mwanja, W. W., G. C. Booton, L. Kaufman \& P. A. Fuerst, (2008): A profile of the introduced Oreochromis niloticus (Pisces: Teleostei) populations in Lake Victoria Region in relation to its putative origin of Lakes Edward and Albert (Uganda - E. Africa) based on random amplified polymorphic DNA analysis. African Journal of Biotechnology 7: 1769-1773

Nelson J.S., 2006, Fishes of the World, 4th edition. Hoboken, NJ: John Wiley and Sons. ISBN 0471250317

Njiru J, van der Knaap M, Kundu R, Nyamweya C., 2018, Lake Victoria fisheries: Outlook and management. Lake. Reser: Res. Managt. 23, 152-162. 
Njiru J, Waithaka E, Aloo P. A., 2017, An Overview of the Current Status of Lake Naivasha Fishery: Challenges and Management Strategies. The Open Fish. Sci. J. 10, $1-11$.

Njiru M, Getabu A, Othina A, Wakwabi E., 2007, Are fisheries management, measures in Lake Victoria successful? The case of Nile perch and Nile tilapia fishery. Afr. J. Ecol. 45, 315-323.

Njiru M, Ojuok J.E, Okeyo-Owuor J.B, Muchiri M, Ntiba M.J, Cowx I.G.,2006, Some biological aspects and life history strategies of Nile tilapia, Oreochromis niloticus (L.) in Lake Victoria, Kenya. Afr. J. Ecol. 44:30-37.

Njiru M, Ojuok J.E., 1997, Population parameters of Oreochromis leucostictus Afr. J. Trap. Hydrobiol. Fish. 7, 17-21

Njiru M, Okeyo-Owuor J.B, Muchiri M, Cowx I.G., 2004, Shifts in the food of Nile tilapia, Oreochromis niloticus (L.) in Lake Victoria, Kenya. Afr. J. Ecol. 42,163-170.

Njiru M. (2003). Ecology and Population Characteristics of Nile tilapia, Oreochromis niloticus (L.) in Lake Victoria, Kenya. PhD Thesis, Moi University, Eldoret, Kenya, 199 p.

Njiru M., Kazungu J., Ngugi C. C., Gichuki J. \& Muhoozi, L.,2008. An overview of the current status of Lake Victoria fishery: Opportunities, challenges and management strategies. Lakes and Reservoirs: Research and management, 13, 1 - 12.

Njiru M., Othina A. N., Getabu A., Tweddle D. \& Cowx I. G., 2002. Is the invasion of water hyacinth, Eichhornia crassipes Solms (Mart.), a blessing to Lake Victoria fisheries. In: Management and Ecology of Lake and Reservoir Fisheries (ed. I. G. Cowx) pp. 255-63. Fishing News Books, London, UK.

Njiru, M., Waithaka, E., Muchiri, M., van Knaap, M. \& Cowx, I.G. (2005). Exotic introductions to the fishery of Lake Victoria: What are the management options? Lakes and Reservoirs: Research and Management 10, 147-155.

Nunan F.(2010) Governance and fisheries co-management on Lake Victoria: challenges to the adaptive governance approach. Mast 9(1): 103-25.

Ogari J., 1984, Distribution, food and feeding habits of Lates niloticus (L) in Nyanza Gulf of Lake Victoria. FAO Fish. Rep. 335, 18-41.

Ogari, J., \& van der Knaap M., 2002. Solarization of water hyacinth, Eichhornia crassipes on Lake Victoria. Fisheries Management and Ecology, 9(6), 365-367. 
Ogutu-Ohwayo R. (1990). The decline of the native fishes of lakes Victoria and Kyoga (East Africa) and the impact of introduced species, especially the Nile perch, Lates niloticus and the Nile tilapia, Oreochromis niloticus. Envi. Biol. Fish. 27, 81-96.

Ojuok J, Njiru M, Mugo J, Morara G, Wakwabi E, Ngugi C., 2008, Increase dominance of Common Carp, Cyprinus carpio L: The boon or bane of Lake Naivasha fisheries? Afr. J. Ecol. 46(3), 445-448.

Ojuok J.E, Mavuti K.M, Ntiba M.J., 2000, Gonadal patterns and reproductive strategy of Nile tilapia Oreochromis niloticus (L.) in the Nyanza Gulf of Lake Victoria. In: Proceedings of Lake Victoria. A new Beginning Conference, 15-19 May 2000, Jinja, Uganda. Lake Victoria Fisheries Organization, Jinja, Uganda: pp 161-168.

Ojuok J.E, Njiru M, Mugo J, Morara G, Wakwabi E, Ngugi,C.,2007, Increased dominance of common carp, Cyprinus carpio (L): the boon or the bane of Lake Naivasha fisheries? Afr. J. Ecol. 46, 445-448.

Outa N, Otieno N, Kitaka J.M, Njiru M., 2014, Length-weight relationship, condition factor, length at first maturity and sex ratio of Nile tilapia, Oreochromis niloticus in Lake Naivasha, Kenya. Int. J. Fish. and Aquat. Stud. 2(2), 67-72.

Outa N. O, Yongo E, Jameslast A. K., 2017, Ontogenetic changes in prey ingested by Nile perch (Lates niloticus) caught in Nyanza Gulf of Lake Victoria, Kenya. Lake. Reser: Res. Managt. 20, 1-5.

Oyugi D.O, Harper D.M, Ntiba M.J, Kisia S.M, Britton J.R., 2011, Management implications of the response of two tilapiine cichlids to long-term changes in lake level, diversity and exploitation in an equatorial lake. Ambio. 40, 469-478.

Parkos J, Santucci VJ Jr, Wahl D. (2003). Effects of common carp (Cyprinus carpio) on multiple trophic levels in shallow mesocosms. Can J Fish Aquat Sci, 60: 82-192.

Petr T., 2000, Interactions between fish and aquatic macrophytes in inland waters: a review. Italy: FAO FTP. (396), 185. Available at: http://trove.nla.gov.au/work/1185996

Philippart C.L., Ruwet J.C.L., 1982, Ecology and distribution of tilapias, p. 15-59. In R.S.V. Pullin and R.H. Lowe-McConnell (eds.) The biology and culture of tilapias. ICLARM Conference Proceedings 7,432 p. International Center for Living Aquatic Resources Management, Manila, Philippines. 
Pringle R. M., 2005, The Nile Perch in Lake Victoria: Local responses and adaptations. J. Int. Afr. Inst. 75, 510- 538. https://doi.org/10.3366/afr.2005.75.4.510

Riedel, R., Caskey, L.M., Hurlbert, S.H. (2007). Length-weight relations and growth rates of dominant fishes of the Salton Sea: implications for predation by fish-eating birds. Lake and Reservoir Management. 23:528-535.

Russell D.J, Thuesen P.A, Thomson F.E., 2012, Reproductive strategies of two invasive tilapia species Oreochromis mossambicus and Tilapia mariae in northern Australia. J. Fish Biol. 80, 2176-2197

Scott W.R, Crossman E.J., 1973, Freshwater fishes of Canada. Bull Fish Res Board Can. 184, $1-966$.

Seehausen O, van Alphen J. J, Witte F., 1997, Cichlids diversity threatened by eutrophication that curbs sexual selection. Science, 277, $1808-1811$.

Shechonge , A., Ngatunga, B. P., Bradbeer, S. J., Day, J. J., Freer, et al.(2019): Widespread colonisation of Tanzanian catchments by introduced Oreochromis tilapia fishes: the legacy from decades of deliberate introduction. Hydrobiologia, 832(1), 235-253.

Sutcliffe J. V., \& Petersen G., 2007. Lake Victoria: Derivation of a corrected natural water level Hydrol. Science Journal, 52(6), 1316-1321.

Trewavas E., 1983, Tilapiine fishes of the genera Sarotherodon, Oreochromis and Danakilia. British Museum of Natural History, London, U.K, 583.

Verschuren, D., T. C. Johnson, H. J. Kling, D. N. Edgington, P. R. Leavitt, E. T. Brown, M. R. Talbot \& R. E. Hecky (2002): History and timing of human impact on Lake Victoria, East Africa. Proceedings of the Royal Society of London B: Biological Sciences 269: 289-294.

Waithaka E, Yongo E, Outa N, Mutethya E. (2020). Population Biology of Nile tilapia (Oreochromis niloticus) in Lake Naivasha, Kenya. Lakes \& Reservoirs Research \& Management. 00:1-6. https://doi.org/10.1111/1re.12319.

Wasonga A.G, Daniel W.A, Brian O., 2017, Interspecific Hybridization of Tilapiines in Lake Victoria, Kenya. J. Fish. \& Liv. Prod. Volume 5:2-9. DOI: 10.4172/2332-2608.1000235

Welcomme R.L., 1964. Notes on the present distribution and habits of non-endemic species of Tilapia which have been introductions into Lake Victoria. EAFFRO Annual Report. (1962-63), 36-39. 
Welcomme R.L., 1967, Observation on the biology of the introduced species of tilapia in Lake Victoria. Revue de Zool. et de Bot. Afr. 526: 249-279.

Welcomme, R.L. 1966. Recent changes in the stocks of tilapia in Lake Victoria. Nat. 212:52-54.

Witte F, Goldschmidt T, \& Wanink J., 1992. The destruction of an endemic species flock: Quantitative data on the decline of the haplochromine cichlids of Lake Victoria. Environ. Biol. Fish, 34, $1-28$.

Witte F, Goudswaard T, Katunzi E. F. B, Mkumbo O. C, Seehausen O, Wanink J. H., 1999, Lake Victoria's ecological changes and their relationships with the riparian societies. In H. Kawanabe, G. W. Coulter, \& A. C. Roosevelt (Eds.), Ancient lakes: Their cultural and biological diversity Belgium: Ken. Prod. pp. 189-202.

Witte, F., Seehausen, O., Wanink, J.H., Kishe-Machumu, M.A., Rensing, M., and Goldschmidt, T. 2013,Cichlid species diversity in naturally and anthropogenically turbid habitats of Lake Victoria, East Africa. Aquat. Sci. 75(2): 169-183. doi:10.1007/s00027-012-02654.

Witte, F., Wanink, J.H., Rutjes, H.A., van der Meer, H.J., and van den Thillart, G.E.E.J.M. 2005, Eutrophication and its influences on the fish fauna of Lake Victoria. In Restoration and management of tropical eutrophic lakes. Edited by M.V. Reddy. Science Publishers, Enfield, N.H., USA. pp. 301-338.

Yongo E, Outa N, Kito K, Matsushita Y. (2018). Studies on the biology of Nile tilapia (Oreochromis niloticus) in Lake Victoria, Kenya: in light of intense fishing pressure, Afr. J. Aquatic Sci. DOI: 10.2989/16085914.2018.1455574.

Yongo E, Outa N, Kito K, Matsushita, Y. (2017a). Some aspects of the biology of Nile perch, Lates niloticus, in the open waters of Lake Victoria, Kenya. Lakes and Reservoirs: Research and Management 20: 1-6.

Yongo E, Outa N, Ngodhe, S.O. (2017b). Effects of Water hyacinth (Eichhornia crassipes Solm) Infestation on water quality, fish species diversity and abundance in the Nyanza Gulf of Lake Victoria, Kenya. Intr. Journal of Fisheries and Aquatic Research. 2(1): 08- 10

Yongo E, Outa N. (2016). Growth and population parameters of Nile tilapia, Oreochromis niloticus (L.) in the open waters of Lake Victoria, Kenya. Lake. Reser: Res. Managt. 21(4), 375-379. https://doi.org/10.1111//re.12154 